\title{
Gökkuşağı Alabalığı (Oncorhynchus mykiss)'na Uygulanan Formaldehit Banyosunun Bazı Hematolojik Kan Parametreleri Üzerine Etkisi
}

\begin{tabular}{|c|c|}
\hline Araştırma / Research & \\
\hline $\begin{array}{l}\text { Gelis Tarihi / Received } \\
\text { 27.03.2017 }\end{array}$ & Hakan BAYRAM, Esat Mahmut KOCAMAN* \\
\hline $\begin{array}{l}\text { Kabul Tarih / Accepted } \\
01.06 .2017\end{array}$ & Atatürk Üniversitesi Su Ürünleri Fakültesi, Erzurum- Türkiye \\
\hline $\begin{array}{l}\text { DOI } \\
\text { 10.28955/alinterizbd.300793 }\end{array}$ & *e-posta: ekocaman@atauni.edu.tr \\
\hline $\begin{array}{l}\text { ISSN 2564-7814 } \\
e-I S S N 2587-2249\end{array}$ & \\
\hline
\end{tabular}

Öz: $\mathrm{Bu}$ araştırmada, balık hastalıklarının tedavisinde yaygın bir şekilde kullanılan formaldehit'in Gökkuşağı Alabalığı (Oncorhynchus mykiss)'nın bazı hematolojik parametreleri üzerine etkisi araştırılmıştır. Araştırmadan elde edilen sonuçlara göre, doz x süre interaksiyonunda ölçülen hematokrit değerleri arasındaki farklılık istatistiksel olarak önemli $(\mathrm{p}<0,05)$ bulunmuştur. Hemoglobin miktarında uygulama dozu ve doz x süre interaksiyonunun istatistiksel anlamda çok önemli $(p<0,01)$, uygulama süresinin ise önemli $(p<0,05)$ olduğu saptanmıştır. Retikülosit oranı bakımından uygulama dozu ile uygulama süresi istatistiksel olarak çok önemli $(\mathrm{p}<0,01)$ olduğu görülmüştür.

Anahtar Kelimeler: Gökkuşağı alabalığı, formaldehit, hematokrit, hemoglobin, retikülosit oran1.

\section{The Effect on Some Hematologic Blood Parameters of Formaldehyde Bath which was Appled to Rainbow Trout (Oncorhynchus mykiss)}

\begin{abstract}
In this study, it was researched the effects of formaldehyde that used commonly at treatment of fish diseases on hematological parameters of rainbow trout (Oncorhynchus mykiss). According to the result of this study, it was found statisticaly significant $(\mathrm{p}<0.05)$ difference among of the hematocrit values that measured at the doses $\mathrm{x}$ the time interaction. From the point of view of the hemoglobin amount, the application of doses and the dose $\mathrm{x}$ time interaction was very significant $(\mathrm{p}<0.01)$ and effect of the application of time was significant $(p<0.05)$. From the point of view of reticulocyte proportion, the application of doses and the application of time interaction was very significant $(\mathrm{p}<0.01)$.
\end{abstract}

Keywords: Rainbow trout, formaldehyde, hematocrit, hemoglobin, reticulocyte rate

\section{GİRIŞ}

Büyüyen ve gelişen sanayi nedeniyle, kültür balıkçılığı için uygun su kaynakları bulmakta zorluk çekilirken, bir yandan da mevcut kaynaklar sürekli kirletilmektedir. Sulardaki zararlı maddeler, endüstri atıklarına bağlı olarak miktar ve çeşitlilik yönünden giderek artmakta ve canlılar için önemli tehlikeler meydana getirmektedir (Atamanalp, 2000). Yerleşim yeri ve endüstriyel üretime bağlı özellikle sıvı atıklar hiçbir arıtıma tabii tutulmadan su kaynaklarına boşaltılmaktadır. Hatta bazı akarsulara yerleşim yerlerinin katı atıklarının da dökülmekte olduğu görülmektedir. Özellikle toksik organik artıkların metallerle birleşerek veya başka bileşiklerine dönüşerek daha da toksik hale geçmeleri önemli sorunlar yaratmaktadır (Atamanalp ve ark., 2002).

Sulardaki bu olumsuz faktörlerin yanı sıra viral, fungal, paraziter vb. hastalık ajanlarının da etkisiyle birçok hastalık meydana gelmektedir. Oluşan bu hastalıklar neticesinde su ürünleri sektöründe her yıl milyonlarca dolarlık kayıplar söz konusu olmaktadır (Snieszko, 1972).

Su ürünleri yetiştiriciliğinde hastalıkların kontrolü ve mücadelesinde çeşitli kimyasallar (metilen mavisi, malahit yeşili, kloramin-T, bakır sülfat, iyodin, potasyum permanganat, formaldehit gibi ) kullanılmaktadır. Bunlar içerisinde özellikle formaldehit (Formalin \%37-40) genelde dezenfektan ve anti paraziter ajan olarak, bakteriyel enfeksiyonların kontrolünde, viral ve fungal hastalıkların tedavisinde kullanılmaktadır (Meinelt ve ark., 2004). 
Kimyasal formülü $\mathrm{H}_{2} \mathrm{CO}$ olan formaldehitin molar kütlesi $30,03 \mathrm{~g} / \mathrm{mol}$, renksiz gaz, yoğunluğu $1 \mathrm{~kg} / \mathrm{m}^{3}$, erime noktas $1-117^{\circ} \mathrm{C}(156 \mathrm{~K})$, kaynama noktas $1-19,3^{\circ} \mathrm{C}(253.9 \mathrm{~K})$ 'dır. Ayrıca formol, metil aldehit ve metilen oksit olarak da adlandırılan formaldehit, kimyasal olarak çözündüğünde beyaz renkli, balıklar için çok zehirli olan paraformaldehite dönüşür (Brown, 1993).

Formaldehit balıkçılıkta protozoasit, antiparazitik ve fungusitlere karşı $250 \mathrm{mg} / \mathrm{L} 1$ saat uygulanmaktadır (Cengizler, 2000). Diğer yandan Brown (1993), formalinin balıklarda banyo metoduyla $17-25 \mathrm{~mL} / 100 \mathrm{~L}$ için 30-60 dakika uygulanmasını, uzun süreli daldırmalarda ise 2 $\mathrm{mL} / 100 \mathrm{~L}$ için 12 saat uygulanmasını bildirmiştir.

Balıklarda her türlü stres faktörleri, su kalitesindeki değişimler, kirlilik faktörleri, toksik maddeler, hastalıklar, beslenme yetersizliği gibi nedenler balığın direk fizyolojik durumunu etkilemektedir. Hematolojik parametreler balığın fizyolojik durumunu belirlemede iyi bir araçtır (Şahan ve Cengizler, 2000).

Hematoloji, balığın kanındaki kan hücrelerini ve bunlarla ilgili kan parametrelerini incelemekte ve değerlendirmektedir. Hematoloji balık hastalıklarının tanısının yanı sıra, beslenme ve çevresel etmenlerin etkilerini de belirleyen bir bilim dalıdır. Hematokrit seviyesi balık sağlığında bir indikatör olarak kullanılmaktadır (Atamanalp ve ark., 2002).

Balıklardaki hematolojik değerler mevsime, çeşitli çevresel faktörlere, beslenme, stok yoğunluğuna, türlere, yaş, uzunluk, ağırlık ve eşey gibi etkenlere bağlı olarak değişebilmektedir (Yılayaz ve Bitmiş, 2002).

$\mathrm{Bu}$ çalışmada formaldehitin solunum metabolizmasını ilgilendiren hematolojik kan parametreleri üzerine olan etkileri araştırılmaya çalışılmıştır.

\section{MATERYAL VE YÖNTEM}

Ortalama canlı ağırlıkları 125 25 g. olan bir yaşındaki Gökkuşağı Alabalıkları (Oncorhynchus mykiss) Atatürk Üniversitesi Ziraat Fakültesi Su Ürünleri Bölümü Yavru Alabalık Üretim ve Araştırma Merkezinden alınmış ve her biri $1 \mathrm{~m}$. çap ve $1 \mathrm{~m}$. derinliğinde olan 12 adet fiberglas tanka 12'şer adet olarak konulmuşlardır.

Araştırmada kullanılan kimyasal madde (Formalin), bir sıvı çözeltide çözünmüş olan formaldehit gazının \%37'lik sıvı halidir. Formaldehit balıklarda ve akuakültürde yaygın bir şekilde kullanılan kimyasal bir maddedir. Kimyasal formülü $\mathrm{H}_{2} \mathrm{CO}$ 'dur. Formaldehit solüsyonu histoloji ve mikroskobik fiksasyonlarda kullanılır. Formaldehitin kimyasal yapısı olarak molar kütlesi $30,03 \mathrm{~g} / \mathrm{mol}$, renksiz gaz, yoğunluğu $1 \mathrm{~kg} / \mathrm{m}^{3}$, erime noktas $-117^{\circ} \mathrm{C}(156 \mathrm{~K})$, kaynama noktas $-19,3^{\circ} \mathrm{C}(253,9 \mathrm{~K}){ }^{\prime}$ dır; diğer isimleri, formol, metil aldehit, metilen oksittir (Anonim, 2008).

Deneme; kontrol dahil 6 gruptan oluşmuştur. Uygulanacak formaldehit miktarı belirlenirken Brown (1993)'ın bildirdiği, formalin 2,0 mL/100 L için 12 saat uygulamasından yararlanılmıştır. Buna dayalı olarak tanklara $250 \mathrm{~L}$ su konularak uygulanacak kimyasal hesaplaması yapılmışıtı. 2,5 mg/250L, 5,0 $\mathrm{mg} / 250 \mathrm{~L}, 7,5 \mathrm{mg} / 250 \mathrm{~L}, 10,0 \mathrm{mg} / 250 \mathrm{~L}, 12,5 \mathrm{mg} / 250 \mathrm{~L}$ su hacmi belirlenen tanklardan $0,4,8,12,24$ ve 48. saatte iki tekerrürlü olarak alınan kanların hematolojileri yapılmış ve birbirlerine göre durumları incelenmiştir.

Kan örneklerinin alınmasında $10 \mathrm{~mL}$ kapasiteli ve 21 numara iğneli plâstik enjektörler Kırım (2005), alınan kanların muhafazasında ise vakumlu ve heparinli kan tüpleri kullanılmıştır (Atamanalp ve ark., 2002). Trombositlerin cama yapışma afinitesinin yüksek olması ve kanın pıhtılaşmasını hızlandırdığından dolayı cam enjektörler yerine plastik enjektörler kullanılmıştır (Atamanalp ve ark., 2002). Kan örnekleri, balıkların anüs yüzgecinin hemen arka kısmı (kaudal vena)'ndan alınmıştır. Kana mukoza karışmaması amacıyla, iyice kurulanıp temizlendikten sonra enjektörle kaudal venadan girilerek $2 \mathrm{~mL}$ civarında alınmıştır (Kırım, 2005). Heparinli tüplere alınan kanlar Atatürk Üniversitesi Ziraat Fakültesi Su Ürünleri Bölümü Hematoloji Laboratuvarında incelenmiştir.

Hemoglobin miktarının tayini için Cyanmet-hemoglobin metodu esas alınmıştır. 0,02 mL kan örneği 5 $\mathrm{mL}$ Drabkin solüsyonuyla karıştııılır. Karışımın yavaş hareketlerle alt üst edilerek homojenitesi sağlanır. Hemoglobinin Cyanmethemoglobine tam olarak dönüşmesi için $10 \mathrm{dk}$ beklenir. Daha sonra dipteki çökelti bir kürdanla çıkarılarak atılır. Spektrofotometrede $540 \mathrm{~nm}$ 'de transmittans (\%T) değeri ölçülür. Elde edilen değere karşılık gelen hemoglobin miktarı standart tablodan bakılarak tespit edilir $\mathrm{g} / 100 \mathrm{~cm}^{3}$ olarak yazılır. Hemoglobin miktarının normal değerleri $4-10 \mathrm{~g} / 100 \mathrm{~cm}^{3}$ arasında değişir (Kozkanç, 2003). 
Hematokrit tayininde hematokrit tüplerine antikoagülantlı kan örnekleri çekilir. Tüplerin bir ucu cam macunu ile kapatılır. Daha sonra hematokrit santrifüje koyularak 10.500 rpm'de 5 dk santrifüj edilir. Santrifüjle birlikte verilen skala üzerinde tüpteki macun kısmının bitiş noktası 0 (sıfır) çizgisine plazmanın bitim noktası da 100 çizgisine çakıştırılır. Daha sonra çökelen şekilli elemanlar kısmının hangi değere denk geldiği skala'dan okunur. Bulunan değer \% olarak ifade edilir. Hematokrit değerinin düşük oluşu anemiyi gösterir (Kırım, 2005).

Retikülosit oranı yayma kan preparatı hazırlanarak May Grunwald Giemsa boyası ile tespit edilmiştir.

Araştırmada elde edilen sonuçlar, SPSS paket programı (SPSS 2004), kullanılarak varyans analizine tabi tutulmuş, önemli bulunan ortalamalar arasındaki farklar Duncan Çoklu Karşılaştırma Testi ile belirlenmiştir (Yıldız, 1986).

\section{ARAŞTIRMA BULGULARI VE TARTIŞMA}

Çizelge 1 'de görüldüğü gibi hematokrit değeri üzerinde doz x süre interaksiyonunun önemli olduğu görülmektedir $(\mathrm{p}<0,05)$. Çizelge 2 incelendiğinde, doz $\mathrm{x}$ süre interaksiyonunda $2,5 \mathrm{~mL} / 250 \mathrm{~L}$ dozundaki uygulama sürelerinde ve 24 saatteki uygulama dozlarında ölçülen hematokrit değerleri arasındaki farklılık istatistiksel olarak önemli $(\mathrm{p}<0,05)$ bulunmuştur. Uygulama dozu ve uygulama süresinin hematokrit değerleri üzerine en yüksek etkiye $\% 59,50$ ile $2,5 \mathrm{~mL} / 250 \mathrm{~L}$ dozunda 24 saat uygulaması sonucu ulaşılırken, en düşük etki ise \%26,00 ile 2,5 mL/250L dozunda 0 saat uygulamasıyla ulaşılmıştır (Çizelge 2). Azizoğlu ve Cengizler, (1996), balıklarda het değerinin \%2544 arasında değiştiğini bildirmişlerdir. Jung ve ark. (2003) ise Dil balıklarında (Paralichthys olivaceus) farklı dozlarda $(100 ; 212 ; 300 \mathrm{ppm})$ formaldehit banyosu uyguladıkları araştırmada Hct değerlerini kontrol grubunda $\% 29,1$ formaldehit uygulanan gruplarda ise sirasiyla \%35,8,\%35, \%36,2 olarak bulmuşlardır. Araştırmadan elde edilen bulgularla Jung ve ark. ( 2003)'nın bildirdiği sonuçlar genel olarak benzerlik göstermektedir. Elde edilen sonuçlar kontrol grubuyla kıyaslandığında formaldehit uygulanan gruplarda Hct değeri önce artmış daha sonra düşmüştür (Çizelge 2). Bazı gruplarda bu duruma uymayan değerler de bulunmaktadır. Blaxhall ve Daisley (1973)'in bildirdiğine göre Hct değeri pek çok faktörden etkilenebilmektedir. Ayrıca Kocabatmaz ve Ekingen (1984) ise alabalıkların Hct değerinin sudaki oksijene karşı oldukça hassas olduğunu ve bununla birlikte çevre şartlarından kolayca etkilenebileceğini bildirmişlerdir. Formaldehitin sudaki oksijeni bağladığ (1993) göz önüne alınırsa Hct değerinin formaldehit konsantrasyonunun yüksek olduğu ilk saatlerde yüksek, daha sonra ise formaldehit konsantrasyonuyla birlikte düşüşe geçmesi benzer çalışmalarla da uyuşmaktadır. Zaten bu durum istatistiki analizlerde de rahatça görülebilmektedir (Çizelge 1). Bazı gruplarda, bu durumla uyuşmayan sonuçların elde edilmiş olması bireysel farklılıklardan kaynaklı olduğunu düşündürebilmektedir.

Çizelge 1. Hematokrit değerine (\%) ilişkin varyans analizi sonuçları

\begin{tabular}{llllll}
\hline Varyasyon Kaynakları & SD & KO & F & p \\
\hline Doz (D) & 5 & 31,648 & 0,739 & 0,599 \\
\hline Uygulama Süre (S) & 5 & 90,428 & 2,111 & 0,86 \\
\hline D x S & 25 & 104,213 & 2,433 & $0,007^{*}$ \\
\hline Hata & 36 & 42,829 & & \\
\cline { 2 - 5 }$p<0,05$ düzeyinde önemli & 71 & & & \\
\hline
\end{tabular}

Çizelge 2. Farklı dozlarda formaldehit içeren tanklarda farklı sürelerde tutulan Gökkuşağı Alabalıkları (Oncorhynchus mykiss)'nın hematokrit değerleri (\%)

\begin{tabular}{|c|c|c|c|c|c|c|c|}
\hline \multirow{3}{*}{$\operatorname{Doz}(\mathrm{mL} / 250 \mathrm{~L})$} & & \multicolumn{6}{|c|}{ Hematokrit (Hct) Değeri (\%) } \\
\hline & & \multicolumn{6}{|c|}{ Uygulama Süre (saat) } \\
\hline & & $\mathbf{0}$ & 4 & 8 & 12 & 24 & 48 \\
\hline & $p$ & & & & & $*$ & \\
\hline $\mathbf{0 , 0}$ & & 31,00 & 38,00 & 40,80 & 39,25 & $40,00 \mathrm{BC}$ & 30,50 \\
\hline 2,5 & $*$ & $26,00 \mathrm{~b}$ & $34,00 \mathrm{~b}$ & $31,50 \mathrm{~b}$ & $35,50 \mathrm{~b}$ & 59,50 a $\mathrm{A}$ & $42,00 \mathrm{~b}$ \\
\hline 5,0 & & 49,50 & 44,00 & 43,00 & 34,50 & $37,50 \mathrm{BC}$ & 38,50 \\
\hline 7,5 & & 40,75 & 43,25 & 43,25 & 36,25 & $30,25 \mathrm{C}$ & 43,00 \\
\hline 10,0 & & 48,50 & 44,00 & 37,50 & 28,75 & $45,25 \mathrm{ABC}$ & 35,00 \\
\hline$\overline{12,5}$ & & 30,75 & 34,25 & 43,00 & 36,50 & $47,00 \mathrm{AB}$ & 36,25 \\
\hline
\end{tabular}

(*)Aynı harfle gösterilen ortalamalar arasında istatistiki olarak önemli fark yoktur $(\mathrm{p}>0,05)$

Küçük harfle gösterilenler dozu; Büyük harfle gösterilenler süreyi belirtmektedir 


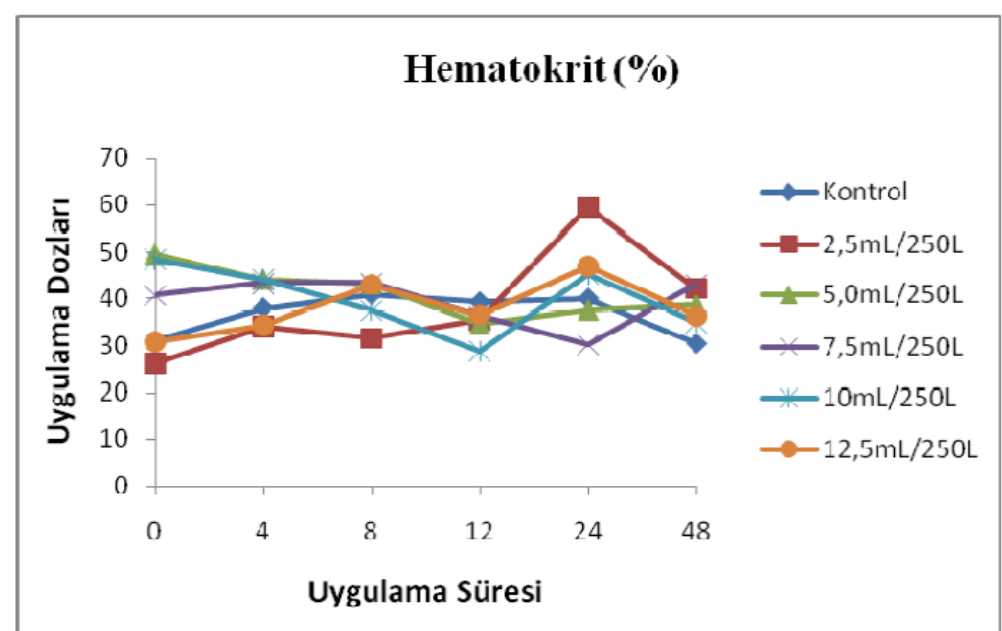

Şekil 1. Farklı dozlarda formaldehit içeren tanklarda farklı sürelerde tutulan Gökkuşağı Alabalıkları (Oncorhynchus mykiss)'nın hematokrit değerleri (\%) diyagramı

Çizelge 3 incelendiğinde hemoglobin miktarı bakımından uygulama dozunun ve doz x süre arasındaki interaksiyonun istatistiksel anlamda çok önemli $(\mathrm{p}<0,01)$, sürenin etkisinin ise önemli $(\mathrm{p}<0,05)$ olduğu görülmüștür. Çizelge 4 incelendiğinde hemoglobin miktarı, uygulama dozu ve süresinin interaksiyonunda $0,4,48$ saatlik uygulama dozlarında ve $2,5-10,0 \mathrm{~mL} / 250 \mathrm{~L}$ uygulama dozlarının sürelerinde önemli $(\mathrm{p}<0,05)$ farklılıklar görülmektedir. Azizoğlu (1995) Hb miktarın 3-6 g/dL olduğunu bildirmiştir. Jung ve ark., (2003), kontrol grubunu 5,5 g/dL ve uyguladığı diğer dozlarda $(100,212,300)$ sirasıyla $7,4 \mathrm{~g} / \mathrm{dL}, 7,2 \mathrm{~g} / \mathrm{dL}, 7,4 \mathrm{~g} / \mathrm{dL}$ olduğunu bildirmişlerdir.

Çizelge 3. Hemoglobin miktarına (g/dL) iliş̧in varyans analizi sonuçları

\begin{tabular}{lllll}
\hline Varyasyon Kaynakları & SD & KO & F & p \\
\hline Doz (D) & 5 & 15,273 & 10,729 & $0,000^{* *}$ \\
\hline Uygulama Süre (S) & 5 & 5,128 & 3,602 & $0,029^{*}$ \\
\hline D x S & 25 & 9,288 & 6,525 & $0,000^{* *}$ \\
\hline Hata & 36 & 1,424 & & \\
\hline Genel Toplam & 71 & & & \\
üzeyinde çok önemli * : p<0,05 düzeyinde önemli & & &
\end{tabular}

Çizelge 4. Farklı dozlarda formaldehit içeren tanklarda farklı sürelerde tutulan Gökkuşağı Alabalıkları (Oncorhynchus mykiss)'nın hemoglobin miktarı (g/dL)

\begin{tabular}{|c|c|c|c|c|c|c|c|}
\hline \multirow{3}{*}{$\operatorname{Doz}(\mathrm{mL} / 250 \mathrm{~L})$} & & \multicolumn{6}{|c|}{ Hemoglobin (Hb) Değeri (\%) } \\
\hline & & \multicolumn{6}{|c|}{ Uygulama Süre (saat) } \\
\hline & & $\mathbf{0}$ & 4 & 8 & 12 & 24 & 48 \\
\hline & $\mathrm{p}$ & $*$ & $*$ & & & & $*$ \\
\hline $\mathbf{0 , 0}$ & $*$ & $5,03 \mathrm{c} \mathrm{BC}$ & $7,09 \mathrm{abC}$ & $6,18 \mathrm{bc}$ & $7,39 \mathrm{ab}$ & $7,98 \mathrm{a}$ & $5,05 \mathrm{cC}$ \\
\hline 2,5 & $*$ & 3,98 c C & $7,25 \mathrm{~b} \mathrm{C}$ & $7,48 \mathrm{~b}$ & $7,40 \mathrm{~b}$ & $10,58 \mathrm{a}$ & $8,20 \mathrm{abAB}$ \\
\hline $\mathbf{5 , 0}$ & & $10,23 \mathrm{~A}$ & $10,23 \mathrm{AB}$ & 6,93 & 6,35 & 9,00 & $10,10 \mathrm{~A}$ \\
\hline 7,5 & & $9,83 \mathrm{~A}$ & $12,00 \mathrm{~A}$ & 9,73 & 9,78 & 6,75 & $8,50 \mathrm{AB}$ \\
\hline 10,0 & $*$ & $10,23 \mathrm{a} \mathrm{A}$ & $8,90 \mathrm{a} \mathrm{BC}$ & $8,70 \mathrm{a}$ & $6,10 \mathrm{bB}$ & $10,08 \mathrm{aA}$ & $8,55 \mathrm{aA}$ \\
\hline 12,5 & & $6,95 \mathrm{~B}$ & $6,85 \mathrm{C}$ & 8,55 & 8,13 & 9,38 & $7,90 \mathrm{~B}$ \\
\hline
\end{tabular}

(*)Aynı harfle gösterilen ortalamalar arsında istatistiki olarak önemli fark yoktur (p>0,05)

Küçük harfle gösterilenler dozu; Büyük harfle gösterilenler süreyi belirtmektedir.

Uygulama dozu ve uygulama süresinin hemoglobin değerleri üzerine en yüksek etkiye 4. saatte 12 $\mathrm{g} / \mathrm{dL}$ ile olduğu gözlenirken, en düşük değere ise kontrol grubunda 0 saat uygulamasıyla ulaşılmıştır (Çizelge 4). Hemoglobin değeri ile Hct arasında sıkı bir ilişki olduğu bilinen bir gerçektir (Kocabatmaz ve Ekingen 1977). Çizelge 2 ve Çizelge 4 'ten de görüleceği gibi Hb ve Hct değerleri benzer bir seyir izlemişlerdir. Hb ve Hct arasındaki bu ilişkiden dolayı Hb değerlerinin Hct'yi etkileyen faktörlerden birebir etkilendiğini söylemek mümkündür. 


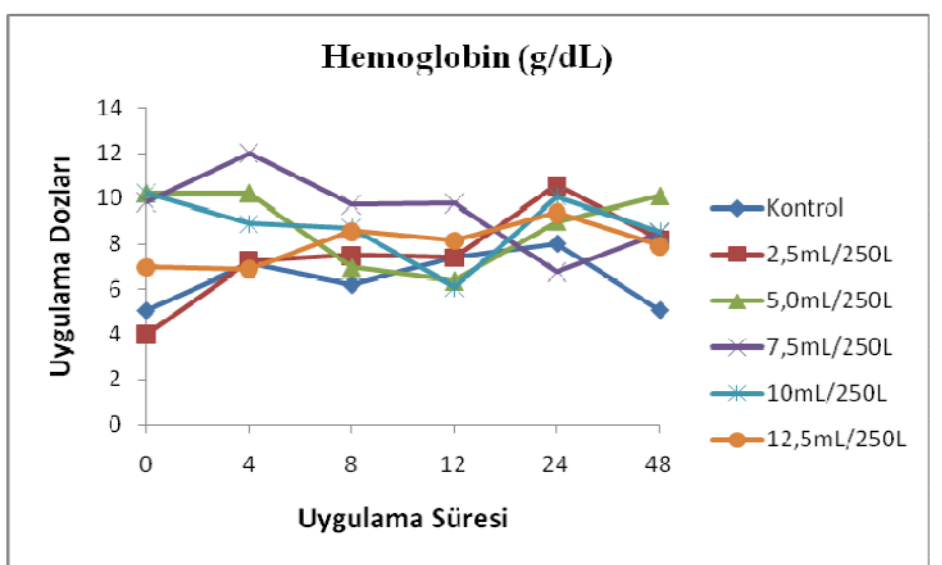

Şekil 2. Farklı dozlarda formaldehit içeren tanklarda farklı sürelerde tutulan Gökkuşağı Alabalıkları (Oncorhynchus mykiss)'nın hemoglobin miktarı (\%) diyagramı

Retikülosit oranı bakımından uygulama dozu ile uygulama süresi arasında istatistiki olarak çok önemli $(\mathrm{p}<0,01)$ bir ilişki olduğu görülmüştür, doz x süre interaksiyonunun ise önemsiz olduğu belirlenmiştir (Çizelge 5). Retikülosit oranında 2,5-10-12,5mL/250L uygulama dozlarındaki sürelerde ve 4 saatlik uygulama süresindeki dozlarda önemli $(\mathrm{p}<0,01)$ farlılıklar görülmüştür.

Eritropoietin fonksiyonları değişik faktörlerden etkilenebilmektedir. Bunlar; oksijen saturasyonu, solunum ve kalp fonksiyonları, kan volumü ve Hb konsantrasyonu gibi faktörlerdir (Müftüoğlu, 1995; Homechaudhuri ve Jha, 2001).

Balıkçılıkta paraziter, fungal ve bakteriyel hastalıklarda oldukça sık kullanılan formaldehitin sudaki çözünmüş oksijeni bağlama yeteneği söz konusudur. Noga (1999)'nın bildirdiğine göre $5 \mathrm{mg} / \mathrm{L}$ formaldehit $1 \mathrm{mg} / \mathrm{L}$ çözünmüş oksijeni bağlamaktadır. Sudaki $\mathrm{O}_{2}$ konsantrasyonunun düşmesiyle birlikte balıklarda eritropoietin aktivitesinin tetiklendiği düşünülmektedir. Çizelge 6. ve Şekil 3'de görüldüğü üzere formaldehit uygulamasının hemen ardından 4'üncü saatten itibaren retikülosit oranında bir artış söz konusu olmakta ve 48 saate doğru bu oran tekrar normalleşmeye başlamaktadır. Retikülosit oranındaki artış eritrosit üretiminin söz konusu olduğunu açıkça göstermektedir (Müftüoğlu, 1995). Araștırmada elde ettiğimiz retikülosit oranının, uygulama dozu ve uygulama süresinin istatistiksel olarak çok önemli $(p<0,01)$ olduğu görülmüştür. Sonuçların benzer çalışmalar ile uyumlu olduğu söylenebilir.

Çizelge 5. Retikülosit Oranına (\%) ilişkin varyans analizi sonuçları

\begin{tabular}{llllll}
\hline Varyasyon Kaynakları & SD & KO & F & p \\
\hline Doz (D) & 5 & 12,242 & 7,438 & $0,000^{* *}$ \\
\hline Uygulama Süre (S) & 5 & 19,534 & 11,868 & $0,000^{* *}$ \\
\hline D x S & 25 & 3,548 & 2,156 & 0,084 \\
\hline Hata & 36 & 1,646 & & \\
\hline Genel Toplam & 71 & & & \\
\hline
\end{tabular}


Çizelge 6. Farklı dozlarda formaldehit içeren tanklarda farklı sürelerde tutulan Gökkuşă̆ Alabalıkları Alınterı (Oncorhynchus mykiss)'nın retikülosit oranı(\%)

\begin{tabular}{|c|c|c|c|c|c|c|c|}
\hline \multirow{3}{*}{$\operatorname{Doz}(\mathrm{mL} / 250 \mathrm{~L})$} & & \multicolumn{6}{|c|}{ Retikülosit Oranı(\%) } \\
\hline & & \multicolumn{6}{|c|}{ Uygulama Süre (saat) } \\
\hline & & $\mathbf{0}$ & 4 & 8 & 12 & 24 & 48 \\
\hline & $\mathrm{p}$ & & $*$ & & & & \\
\hline $\mathbf{0 , 0}$ & $*$ & $2,17 \mathrm{~b}$ & $2,94 \mathrm{~b} \mathrm{C}$ & $3,60 \mathrm{~b}$ & $3,81 \mathrm{~b}$ & $6,01 \mathrm{a}$ & $2,82 \mathrm{~b}$ \\
\hline 2,5 & $*$ & $2,80 \mathrm{~b}$ & $10,28 \mathrm{aA}$ & $5,13 \mathrm{~b}$ & $5,19 \mathrm{~b}$ & $4,75 \mathrm{~b}$ & $5,37 \mathrm{~b}$ \\
\hline $\mathbf{5 , 0}$ & & 2,94 & $6,44 \mathrm{~B}$ & 3,90 & 5,08 & 4,30 & 3,70 \\
\hline 7,5 & & 2,72 & $5,61 \mathrm{BC}$ & 4,81 & 5,70 & 4,41 & 1,96 \\
\hline 10,0 & $*$ & $1,90 \mathrm{bc}$ & $4,84 \mathrm{aBC}$ & $5,031 \mathrm{a}$ & $5,32 \mathrm{a}$ & $4,31 \mathrm{ab}$ & $1,48 \mathrm{c}$ \\
\hline 12,5 & $*$ & $0,84 \mathrm{c}$ & $4,69 \mathrm{aBC}$ & $3,15 \mathrm{~b}$ & $3,33 \mathrm{~b}$ & $1,67 \mathrm{c}$ & $1,77 \mathrm{c}$ \\
\hline
\end{tabular}

$(*)$ Aynı harfle gösterilen ortalamalar arsında istatistiki olarak önemli fark yoktur $(\mathrm{p}>0,05)$

Küçük harfle gösterilenler dozu; Büyük harfle gösterilenler süreyi belirtmektedir

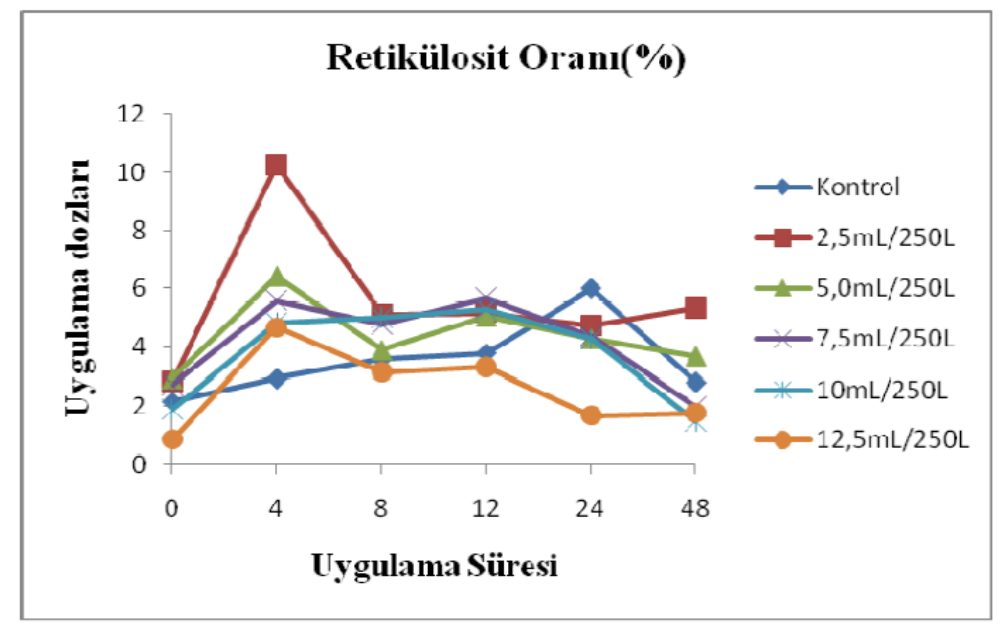

Şekil 3. Farklı dozlarda formaldehit içeren tanklarda farklı sürelerde tutulan Gökkuşağı Alabalıkları (Oncorhynchus mykiss)'nın retikülosit oranı (\%) diyagramı

\section{SONUC VE ÖNERILLER}

Her türlü yetiştiricilikte kimyasal madde kullanımının en az düzeyde tutulması önemli bir unsurdur. Kimyasalların kullanımı önceden bilinmeyen çeşitli yan etkilere neden olabileceği gibi insan sağlığı açısından da zararlı sonuçlar doğurabilir. Balık hastalıklarının tedavisinde yaygın olarak kullanılan formaldehitin kullanımı esnasında solunum problemlerine sebep olabileceği bilinmektedir. Formaldehitin özellikle toprak havuzlarda kullanımında fitoplankton aktivitesinin de göz önünde bulundurulması gerekmektedir. Formaldehit banyosu uygulanırken bu maddenin balıklarda deri ve solunum sistemindeki irritasyon etkisinin de dikkate alınarak uygulama dozuna dikkat edilmesi gerektiği sonucuna varılmıştır.

\section{KAYNAKLAR}

Anonim, 2008. Formaldehyde. From Wikipedia, the free encyclopedia, http://en.wikipedia.org/wiki/Formaldehyde, (Erişim tarihi:13.07.2008).

Atamanalp, M., 2000. Bir sentetik piretroit insektisitin (Cypermethrin) subletal dozlarının Gökkuşağı Alabalığı (Oncorhynchus mykiss)'na makroskobik, hitopatolojik, hematolojik ve biyokimyasal etkiler. Doktora tezi, Atatürk Üniversitesi Fen Bilimleri Enstitüsü (Basılmamış), Erzurum.

Atamanalp, M., Kocaman, E. M., ve Canyurt, M. A., 2002. Kentsel atıkların Capoeta capoeta capoeta (Güldenstaedt, 1772)'nın hematokrit ve sediment seviyeleri üzerine etkileri. Ege Üniversitesi Su Ürünleri Fakültesi Su Ürünleri Dergisi 19 (3-4):439-445.

Azizoğlu, A., 1995. Sağlıklı Oreochromis niloticus (L.)bireylerinde bazı hematolojik parametrelerin saptanması üzerine bir araştırma, Yüksek lisans tezi, Çukurova Üniversitesi Fen Bilimleri Enstitüsü(Basılmamış), Adana.

Azizoğlu, A. ve Cengizler İ., 1996. Sağlıklı Oreochromis niloticus (L.) bireylerinde bazı hematolojik parametrelerin saptanması üzerine bir araștırma. Turkish Journal Of Veterinary And Animal Sciences 20: 425-431.

Blaxhall, P. C., and Daisley, K. W., 1973. Routine haematological methods for usefish with blood. J. Fish Biol. 5: 
771-781.

Brown, L., 1993. Aquaculture For Veterinarians Fish Husbandry and Medicine. Pergamon Press, North Chicago, USA, 138-139.

Cengizler, İ., 2000.Balık Hastalıkları. Çukurova Üniversitesi Su Ürünleri Fakültesi Yayınları: 7, Adana

Homechaudhuri, S., Jha, A., 2001. A Technique to evaluate the erythropoietic efficiency in fish. Asian Fisheries Science 14: 453-455.

Jung, S. H., Sim D. S., Park, M., Jo, Q., and Kim, Y., 2003. Effects of formalin on haematological and blood chemistry in olive flounder, paralichthys olivaceus (Temminck et Schlegel). Aquaculture Research 34: 1269-1275.

Kırım, B., 2005. Fotoperiyodun damızlık Gökkuşağı Alabalıklarında (Oncorhynchus mykiss) yumurtlama zamanı, yağ asidi komposizyonu, kuluçka performansı ve hematolojik parametreler üzerine etkisi. Doktora tezi, Atatürk Üniversitesi Fen Bilimleri Enstitüsü (Basılmamış), Erzurum.

Kocabatmaz, M., Ekingen, G., 1977. Preliminary investigations on some hematological norms in five freswater fish species. Frrat Üniversitesi Veterinerlik Fakültesi Dergisi 4 (1-2): 28-40.

Kocabatmaz, M., Ekingen, G., 1984. Değişik tür balıklarda kan örneği alınması ve hematolojik metotların standardizasyonu. Doga Bilim Dergisi D1, 8, 2.

Kozkanç, Y., 2003. Fenoksietanol ile hipoderminin Gökkuşağı Alabalığı (Oncorhynchus mykiss) hematolojik parametreleri üzerine etkilerinin araştırılması. Yüksek lisans tezi, Atatürk Üniversitesi Fen Bilimleri Enstitüsü (Basılmamış), Erzurum.

Meinelt, B. T., Pietrock, M., Burnison, K., Steinberg, C., 2004. Formaldehyde toxicity is altered by calcium and organic matter. Blackwell Verlag, 21 (2005), 121-124.

Müftüoğlu, E., 1995. Klinik Hematoloji. Şafak Yayıncılık, s 8, Diyarbakır.

Noga, J. E., 1999. Fish disease diagnosis and treatment. Iowa State University. Blacwell publishing company, Iowa 286.

Şahan, A., Cengizler, İ., 2000. Seyhan baraj gölü ve Seyhan hehrinde yasayan Aynalı Sazan (Cyprinus carpio, Linnaeus 1758)'larda bazı kan parametrelerinin belirlenmesi. Turkish Journal Of Veterinary And Animal Sciences 24: 205-214

Snieszko, S. F., 1972, Nutritional fish diseases. Fish Nutrition. Halver, J.E. (ed.). Academic Press, London. p 403-437.

Yılayaz, Ö., Bitmiş, K., 2002. Keban baraj Gölü’nde yaşayan Barbus rajanorum mystaceus (Heckel, 1843)'da kan parametrelerinin incelenmesi. Gazi Üniversitesi Gazi Eğitim Fakültesi Dergisi 22 (2): 11-21.

Yıldız, N., 1986, Araştırma ve Deneme Metotları. Atatürk Üniversitesi Yayınları: 697, Ziraat Fakültesi Yayınları: 305, Ders Kitab1, Erzurum. 